\title{
Ankara tavşanında endokrin pankreas üzerine ışık ve elektron mikroskobik araştırmalar
}

\author{
Nejdet ŞIMSŞEK ${ }^{1}$, Emel ERGÜN ${ }^{2}$, Levent ERGÜN $\mathbf{N}^{3}$ \\ ${ }^{1}$ Atatürk Üniversitesi, Veteriner Fakültesi, Histoloji ve Embriyoloji Anabilim Dalı, Erzurum; ${ }^{2}$ Kırıkkale Üniversitesi, Veteriner \\ Fakültesi, Histoloji ve Embriyoloji Anabilim Dalı, Kırıkkale; ${ }^{3}$ Ankara Üniversitesi, Veteriner Fakültesi, Histoloji ve Embriyoloji \\ Anabilim Dalı, Ankara.
}

\begin{abstract}
Özet: $\mathrm{Bu}$ çalışmada, Ankara tavşanlarının (10 adet, sağlıklı ve erişkin) endokrin pankreası histokimyasal ve elektron mikroskobik olarak incelendi. Tavşanlardan alınan pankreas örnekleri Bouin, Carnoy ve gluteraldehit-paraformaldehit solüsyonlarında tespit edildi. Aldehit fuksin light green orange G (AF) ile histokimyasal olarak boyanan pankreas kesitlerinde 2 tip endokrin hücre belirlenmesine rağmen, elektron mikroskobik incelemelerde endokrin adacıkların A, B ve D hücrelerinden oluştuğu gözlendi. Langerhans adacıklarının merkezinde mor-menekşe boyanan çok sayıda B hücrelerinin ve periferinde sarımsı-yeşil boyanan az sayıda A hücrelerinin bulunduğu saptandı. Elektron mikroskobik olarak, A hücrelerinin salgı granülü genellikle yuvarlak ve elektron çok yoğun iken, B hücrelerinin sitoplazmasında salgı içeriği ile salgı membranı arasında belirgin boşluk bulunan elektron çok yoğun ve elektron az yoğun granüller tespit edildi. D hücrelerinin de elektron çok yoğun ve elektron az yoğun materyale sahip yuvarlak 2 çeşit granül içerdiği ancak, bu granüllerin A ve B hücrelerinin granüllerinden daha küçük olduğu gözlendi. Bu çalışmanın sonucunda, Ankara tavşanı endokrin pankreasının çok sayıda B hücreleri, az sayıda A hücreleri ve çok az sayıda da D hücrelerinden oluştuğu saptand1.
\end{abstract}

Anahtar sözcükler: Ankara tavşanı, elektron mikroskop, endokrin pankreas.

\section{Light and electron microscopic investigations on the endocrine pancreas in Angora rabbit}

Summary: The endocrine pancreas of the Angora rabbits (10 healthy adult) was examined in this study using histochemistry and electron microscopy. Pancreas samples taken rabbits were fixed in Bouin, Carnoy, and gluteraldehyde-paraformaldehyde solutions. Although, two endocrine cell types was determined in sections of pancreas staining as histochemical by aldehyde fuchsine light green orange G (AF), endocrine islets were constituted by A, B and D cells in electron microscopical examination. The centre of the Langerhans islets were occupied predominantly by B cells stained purple-violet and surrounded a few by A cells stained yellowish-green. Secretory granules of A cells generally were spherical and high electron-dense whereas in the cytoplasm of B cells were determined high electron-dense and low electron- dens granules, have a halo between the membrane and their content. D cells were observed contain to round two kinds of secretory granules, have high electron-dense and low electron-dense material, but smaller than those A and B cell types. In conclusion, the endocrine pancreas of the Angora rabbits were constituted by numerously B cells, a few A cells, and infrequently D cells.

Key words: Angora rabbit, electron microscopy, endocrine pancreas.

\section{Giriş}

Pankreas, sindirim enzimlerini salgilayan ekzokrin bölüm ile karbonhidrat metabolizmasını düzenleyen endokrin bölümden oluşur. Bu organ 2. ve 3. lumbal vertebralarla ilişkili olarak duodenumun kolları arasına retroperitoneal yerleşen ve kuyruk kısmı dalağa kadar uzanan bir organdır (21). Langerhans adacikları olarak adlandırılan endokrin pankreas, ekzokrin dokunun içerisine gelişigüzel yerleşmiş oval ya da yuvarlak alanlardır. Bu adacıklarda başlıca $\mathrm{A}, \mathrm{B}, \mathrm{D}$ ve PP hücreleri bulunmaktadır $(25,26)$. Bunlara ek olarak $\mathrm{C}$ hücreleri adıverilen olgunlaşmamış ya da salgılarını kaybetmiş pankreatik endokrin hücrelerle birlikte (13), enterokromaffin, vazointestinal polipeptid, gastrin (29) ve ghrelin salgilayan enteroendokrin sisteme ait hücrelerin de pankreasta bulunduğu bildirilmektedir (1).

Alfa (A ya da A2) hücreleri glukagon salgılar ve kan glukoz oranını artırmaktadır $(23,25)$. Bu hücreler, atlarda Langerhans adaciklarının merkezinde (30), koyun, köpek ve domuzda adacık periferinde bulunurken (4), bıldırcında alfa adacığı olarak özelleşmiş adacıklarda yer almaktadır (26). Türler arasında, A hücrelerinin elektron mikroskobik özellikleri hemen hemen aynı olup sitoplazmaları elektron koyu salgı granülleri ile doludur $(6,10,26)$. Beta hücreleri (B), insülin salgilar ve amilinin antagonistidir (23, 25). Atlarda adacik periferinde (30), koyun, domuz, köpek (4), fare, rat ve insanda adacık merkezinde (30), bıldırcında ise özelleşmiş beta 
adacıklarında bulunmaktadırlar (26). B hücre granülleri insan, rat, fare ve kobayda yuvarlak (10), kedi ve köpekte poligonal ya da dikdörtgen şeklindedir (9). Bu hücreler, adacıktaki diğer endokrin hücrelere göre mitokondriyon, Golgi kompleksi ve granüllü endoplazma retikulumundan (gER) zengin olup, çekirdekleri de A hücre çekirdeklerinden daha büyüktür $(4,6)$. B hücrelerin ergastoplazmadan zengin olmas1, elektron mikroskopta diğer endokrin hücrelere göre daha koyu görünmesine neden olduğu bildirilmektedir (20). Somatostatin sentezleyen D (A1 ya da $\delta$ ) hücresi metabolik duruma göre glukagon ya da insülin salınımı üzerine de baskılayıcı role sahiptir (23, 25). Sığırda (22) ve keçide (24) adacık periferine ve merkezine, tavşan ve ratta adacık periferine, kedide, köpekte ve insanda adacık hücreleri arasına rasgele yerleşirken (3), atlarda adacık periferinden başka nadiren duktus epitelinde (17), bildırcinda (26), tavukta, kedide ve köpekte hem ekzokrin pankreasta hem de endokrin pankreasta bulunabilmektedir (3). Pankreatik polipeptid hormonunu salgılayan hem endokrin adacıklarda hem de asinuslar arasinda bulunan pankretik polipeptid (PP ya da F) hücresi $(23,25)$; midenin tuz asiti üretimini durdurma, gastrine karşı antagonist etki yapma ve ekzokrin pankreasın sekresyonunu azaltma gibi özelliklere sahiptir (22), Bu hücreler diğer endokrin hücrelere göre çok küçük olması ve az sayıda salgı granülü içermesi ile ayırt edilir (6). Endokrin adacıklarda az sayıda bulunan bu hücrelerin daha çok pankreasın duodenuma komşu bölgelerindeki asinuslar arasında ve ventral pankreasta görülebildiği bildirilmektedir $(15,22,30)$.

Literatür taramalarında tavşan (16), kobay (6), sığır, keçi (22), rat (8), fare, kedi (10), maymun (28) ve bildırcın (26) gibi pek çok hayvanın endokrin pankreası üzerine birçok araştırma yapıldığı belirlenmesine rağmen bölgesel bir ırk olan Ankara tavşanı endokrin pankreası üzerine histolojik bir çalışmaya rastlanmamıştır. Bu araştırmada, Ankara tavşanı endokrin pankreasının histokimyasal ve elektron mikroskobik özellikleri incelenmiştir.

\section{Materyal ve Metot}

Çalışmada materyal olarak, özel yetiştiricilerden sağlanan 10 adet sağlıklı ve erişkin Ankara tavşanı, etik ilke ve kurallara (No: 06/02) uygun olarak kullanılmıştır. Histokimyasal ve elektron mikroskobik incelemeler için yüksek doz eter anestezisi ile ötenazi uygulanan tavşanların pankreası çıkartılarak endokrin hücrelerce zengin olduğu bilinen dalak lobundan doku örnekleri alındı. Dokular 1şık mikroskobik incelemeler için Bouin ve Carnoy solüsyonlarında tespit edildi. Daha sonra dereceli alkoller ve ksilolden geçirilerek paraplastla bloklandı. Bloklardan elde edilen 5-6 mikronluk kesitlere dokunun genel yapısını göstermek için Crossman tarafindan modifiye edilen Mallory'nin üçlü boyaması ile A ve B hücrelerini belirlemek için aldehit fuksin light green orange $\mathrm{G}$ (AF) boyaması yapıldı (5).

Elektron mikroskobik incelemeler için alınan doku örnekleri Karnovsky (19) metoduna göre gluteraldehitparaformaldehit ( $\mathrm{pH}$ 7.4) ön tespitinde 24 saat bekletildikten sonra kakodilat tamponunda y1kanarak ozmik asitte ikinci kez tespit edildi. Dereceli alkoller ve propilen oksitten geçirilerek araldit M'de bloklandı. Bu bloklardan alınan yarı ince kesitlere toluidine blue boyası yapıldı. Yarı ince kesitlerde elektron mikroskobik incelemeler için aranan bölgeler işaretlendi ve $300-400$ Angström kalınlığında ince kesitler alındı. Uranil asetat ve kurşun sitrat ile kontrast boyaması (27) yapıldıktan sonra Carl Zeiss EM 9 S-2 model transmission elektron mikroskopta incelendi.

\section{Bulgular}

Işık mikroskobik incelemelerde, endokrin pankreasın ekzokrin pankreas paranşimi içerisine irili ufaklı, oval şekilli adacıklar halinde rasgele dağıldığı belirlendi. Bouin ve Carnoy olmak üzere iki farklı tespit solüsyonunda tespit edilen pankreasın üçlü boyama ve $A F$ ile boyamalarına karşı farklı reaksiyonlar verdiği saptandı. Bouin tespiti yapılan dokulardan alınan seri kesitlerin üçlü boyamasında $\mathrm{A}$ hücrelerinin asit fuksin ile pembe renkte, B hücrelerinin anilin blue ile açık mavi tonda boyandığ (Şekil 1A), aldehit fuksin boyamasında ise A hücrelerinin sarımsı-yeşil, B hücrelerinin mor-menekşe renk aldıkları tespit edildi (Şekil 1B). Ayrıca, Bouin tespitli pankreaslarda Langerhans adacıkları periferinin A hücrelerinden, merkezinin ise daha çok $\mathrm{B}$ hücrelerinden oluştuğu da gözlendi (Şekil 2A). Gluteraldehit-paraformaldehit tespiti yapılan yarı ince kesitlerin toluidine blue boyamasında, adacık periferindeki A hücrelerinin toluidine blue pozitif granüller içerdiği görülürken, diğer endokrin hücre sitoplazmalarının boya almadığı saptandı (Şekil 2B). Carnoy tespiti yapılan dokuların üçlü boyamasında A hücrelerinin anilin blue ile mavi, B hücrelerinin asit fuksin ile açık pembe boyandığı (Şekil $3 \mathrm{~A}), \mathrm{AF}$ boyamasına ise bütün endokrin hücrelerin negatif reaksiyon verdikleri belirlendi (Şekil 3B).

Elektron mikroskobik incelemelerde endokrin adacıkların merkezinin çok sayıda B hücresi, periferinin bir kaç adet $\mathrm{A}$ hücresi ve nadiren görülen $\mathrm{D}$ hücresinden oluştuğu belirlendi. Daha çok adacık periferine yerleşen A hücrelerinin genellikle bir kenara itilmiş, yuvarlak şekilli ve ökromatik yapıdaki çekirdeğe, çekirdek merkezine yakın bölgede 1 ya da 2 adet çekirdekçiğe, yuvarlak, elektron koyu ve irili ufaklı salgı granülleriyle dolu sitoplazmaya sahip oldukları belirlendi. Ayrıca, sitoplazmada bulunan bu granüllerin bazılarının çeperinde az miktarda da olsa boşluklar bulunduğu da gözlendi (Şekil 4). Adacık merkezini dolduran $\mathrm{B}$ hücrelerinin $\mathrm{A}$ hücre çekirdeklerine göre daha heterokromatik ve oval yapıda 

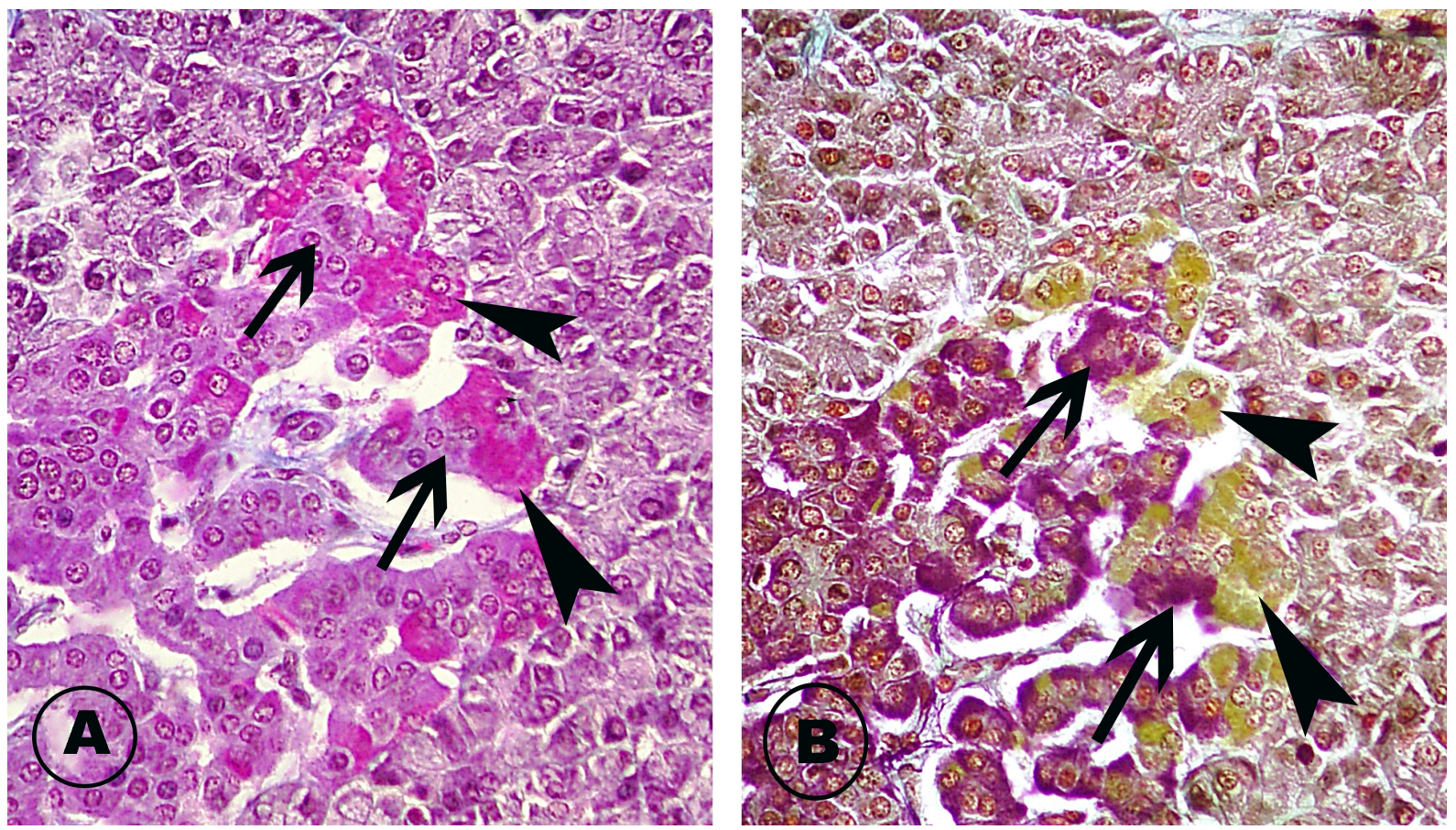

Şekil 1. Bouin tespitli pankreasta A ve B hücreleri. A: üçlü boyama, B: Aldehit fuksin light green orange G boyaması (AF). B hücreleri (oklar), A hücreleri (ok başları). X 325.

Figure 1. A and B cells in pancreas fixed by Bouin. A: triple stain, B: AF stain. B cells (arrows), A cells (arrow heads). X 325.

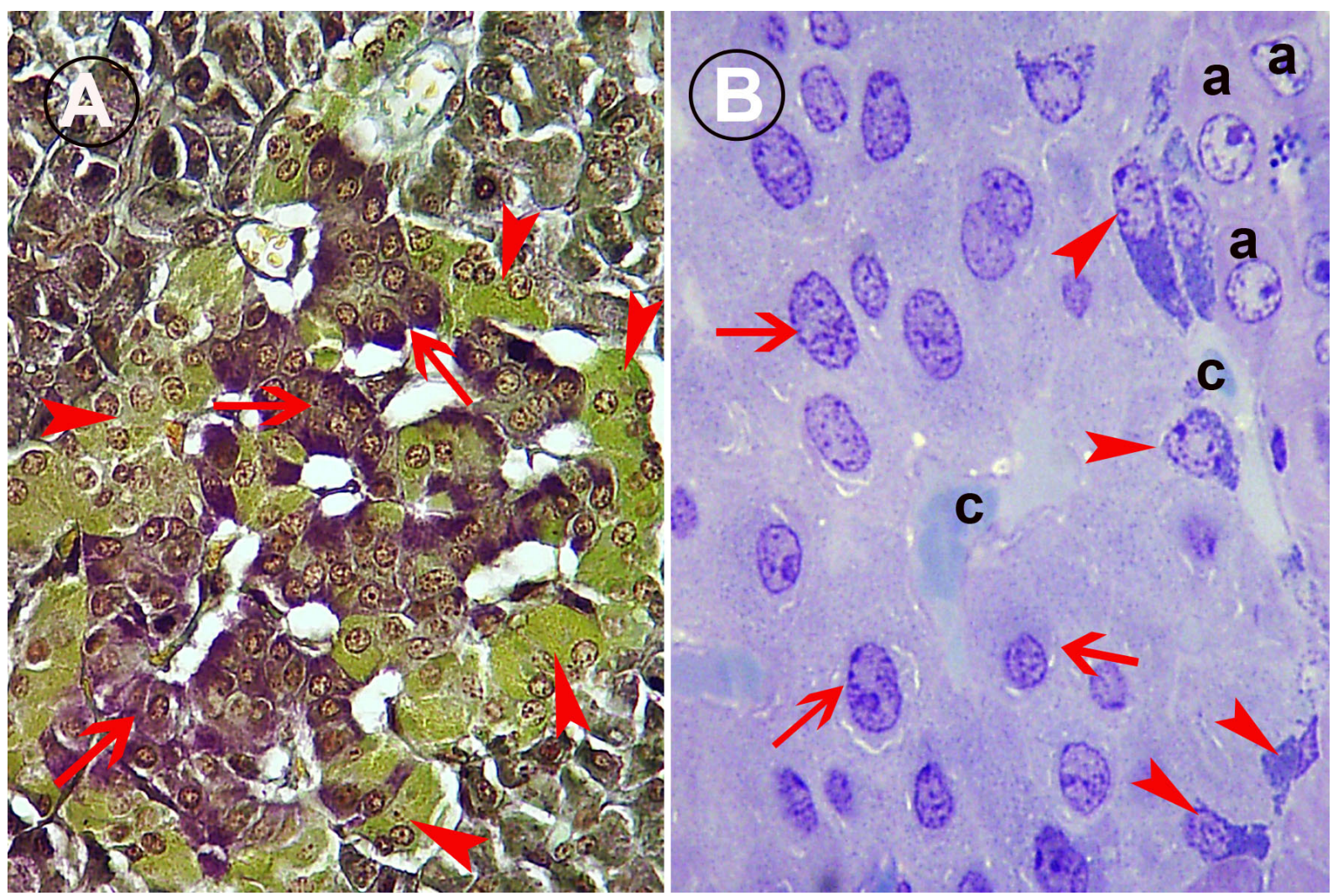

Şekil 2. A: Langerhans adacıklarında A ve B hücrelerinin dağılımı. A hücreleri (ok başları), B hücreleri (oklar). AF boyama. X 450. B: Yarı-ince kesitte endokrin hücrelerin görünüşü. Toluidin blue pozitif A hücreleri ( ok başları), toluidin blue negatif endokrin hücreler (oklar), asiner hücreler (a), kapillar damarlar (c). Yar1-ince kesit, toluidin blue boyama. X 1100.

Figure 2. Distrubition of A and B cells in Langerhans islets. A cells (arrow heads), B cells (arrows). AF stain. X 450. B: The showing of the endocrine cells in semi-thin section. Toluidine blue positive A cells (arrow heads), toluidine blue negative endocrine cells (arrows), acinar cells (a), capillar veins (c). Semi-thin section, toluidine blue stain. X1100. 

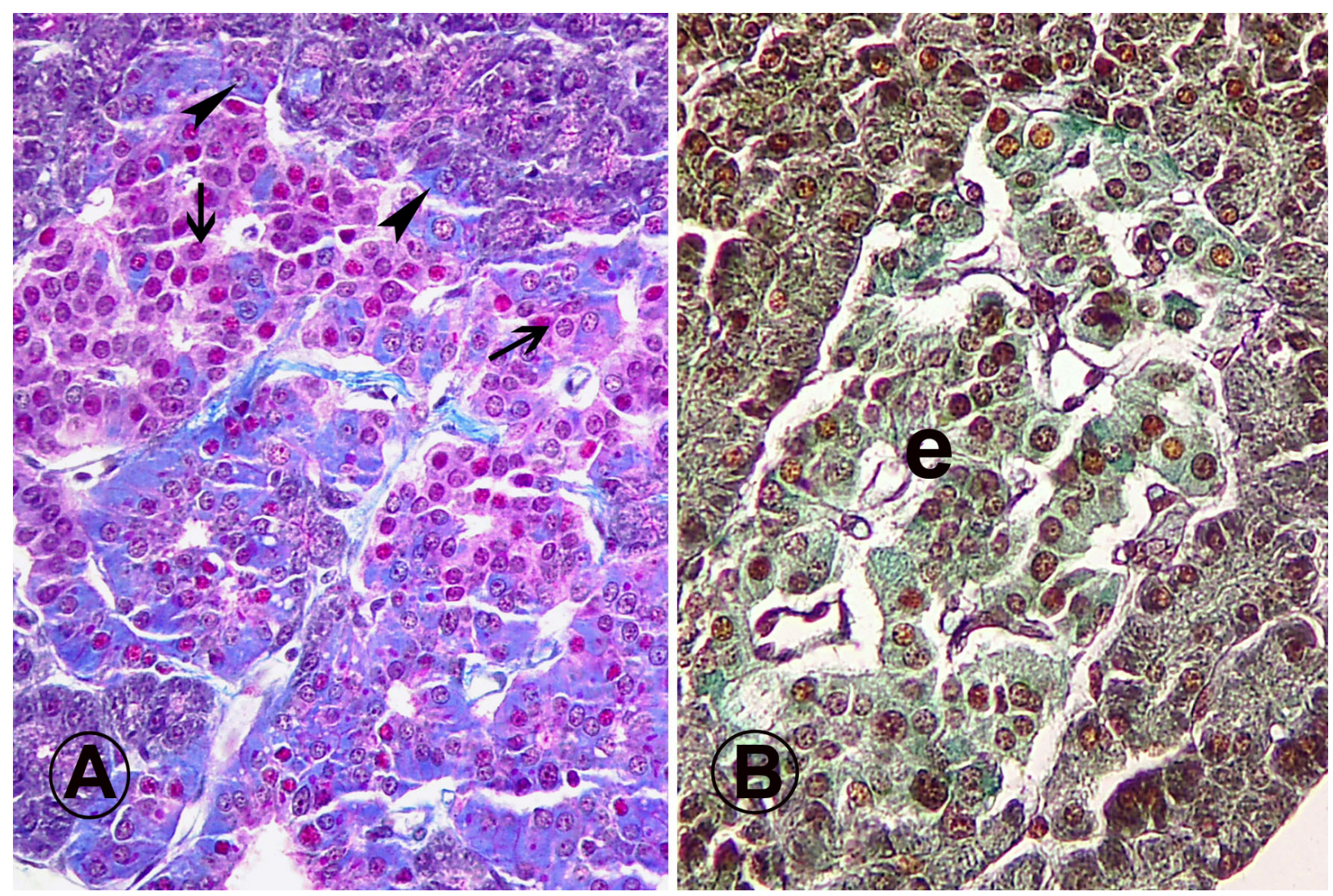

Şekil 3. Carnoy tespitli pankreasta A ve B hücrelerinin belirlenmesi. A hücreleri (ok başları), B hücreleri (oklar). A: Üçlü boyama. X325. B: AF negatif endokrin alan (e). AF boyama. X350

Figure 3. A: Determination of A and B cells in pancreas fixed by Carnoy. A cells (arrow heads), B cells (arrows). Triple stain. X 325. B: AF negative endocrine area (e). AF stain. X350

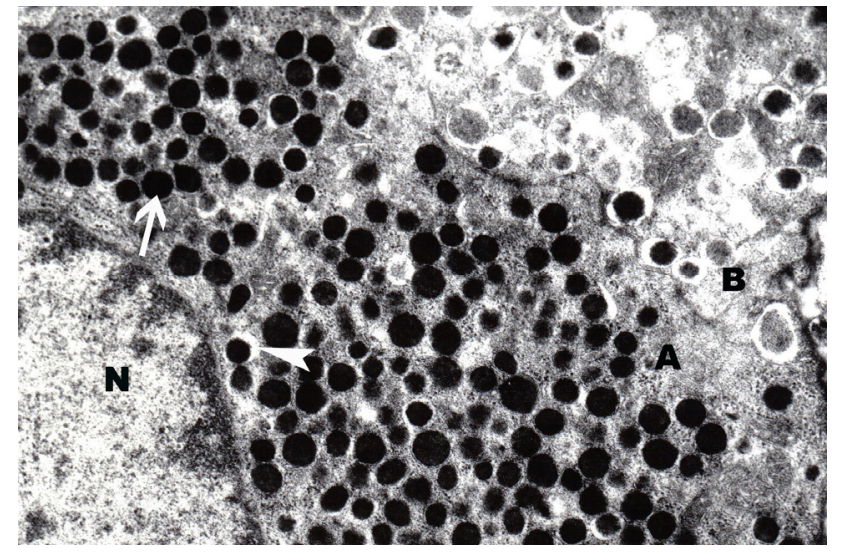

Şekil 4. A hücresinin elektron mikroskobik görünümü. A hücresi (A), B hücresi (B), çekirdek $(\mathrm{N})$, elektron çok yoğun granüller (ok), salgı içeriği ile salgı membranı arasında belirgin boşluk bulunan granül (ok başı). X 22200.

Figure 4. Electron microscopic showing of the A cell. A cell (A), B cell (B), nucleus (N), high electron dense granules (arrow), granules have a clear void between the secret material and the secret membran (arrow head).X 22200.

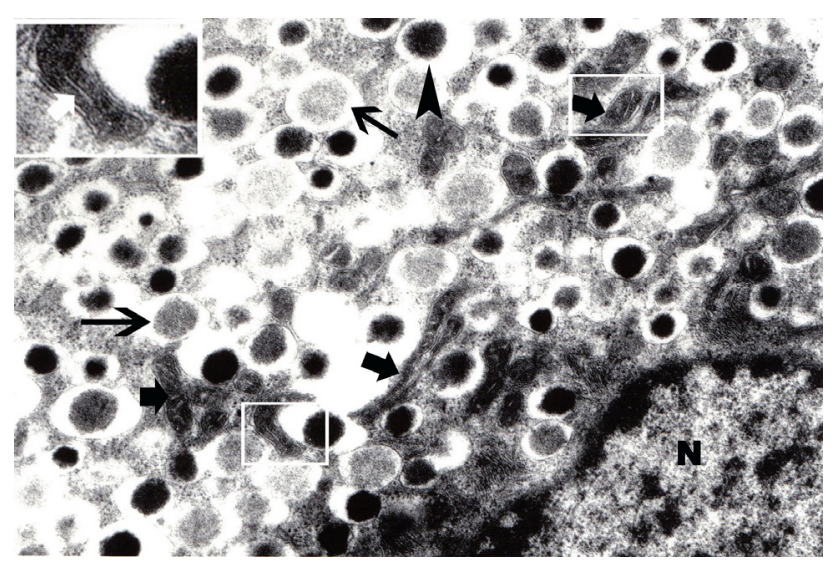

Şekil 5. B hücresinin elektron mikroskobik görünümü. Çekirdek $(\mathrm{N})$, salgı içeriği ile granül membranı arasında vakuoler açıklık bulunan elektron az yoğun granüller (oklar), salg1 içeriği ile granül membranı arasında vakuoler açıklık bulunan elektron çok yoğun granüller (ok başları), mitokondriyonlar (kalın oklar ve dikdörtgen). X 23750.

Figure 5. Electron microscopic showing of the B cell. Nucleus $(\mathrm{N})$, light electron- dense granules have a vacuolar space between the secret material and the secret membran (arrows), high electron- dense granules have a vacuolar space between the secret material and the secret membran (arrow heads), tubules types mitochondrion (bold arrows and rectangle). X 23750. 


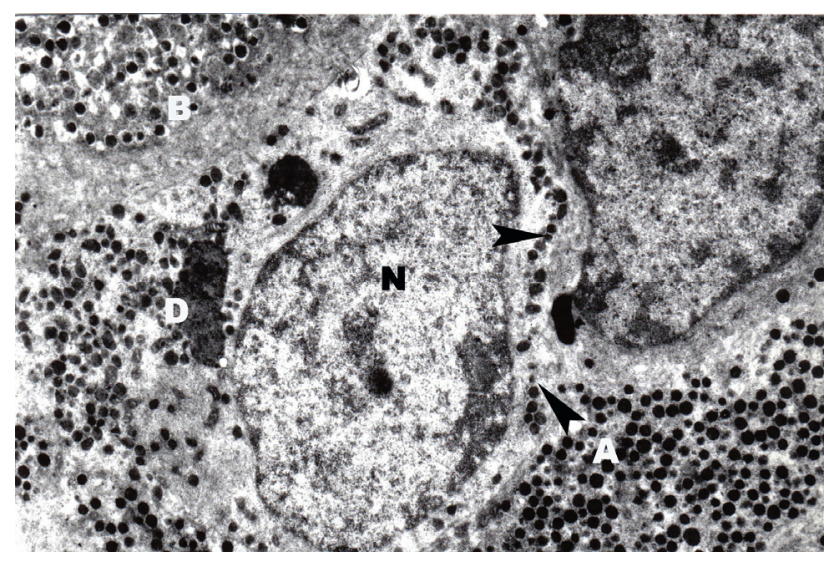

Şekil 6. D hücrelerinin elektron mikroskobik görünümü. Çekirdek (N), D hücresi (D), A hücresi (A), B hücresi (B), irili, ufaklı salgı granülleri (ok başları). X 10575.

Figure 6. Electron microscopic showing of the D cells. Nucleus (N), D cell (D), A cell (A), B cell (B), large and small secret granules (arrow heads). X 10575.

çekirdeğe sahip olduğu, sitoplazmalarının yuvarlak, elektron yoğun ve elektron az yoğun salgı granüllerinden, tubulus tipi mitokondriyonlardan ve ribozomlardan zengin olduğu tespit edildi (Şekil 5). Ayrıca, B hücre granüllerinin salg1 materyali ile granül çeperi arasında vakuoler bir boşluk içerdiği de saptandı (Şekil 5). Endokrin alanlarda A ve B hücre granüllerine göre daha küçük ve az sayıda granülleri olan D hücrelerine de rastlandı. Genellikle oval çekirdek içeren bu hücrelerin sitoplazmasında tespih tanesi gibi art arda dizilmiş elektron az yoğun ve elektron çok yoğun granüllerin oval ve yuvarlak şekilli oldukları belirlendi (Şekil 6).

\section{Tartışma ve Sonuç}

Yapılan çalışmalarda $(6,8,10,26,28)$ memeli ve kanatlı pankreasının elektron mikroskobik yapısı ile sitokimyasal özellikleri belirlenerek türler arasındaki farklılıklara değinilmiştir. Memelilerde Langerhans adacıklarının yuvarlak ya da oval şekilli görünümleriyle asinuslar arasına rasgele dağıldığı, damardan zengin, retiküler bağ dokuyla çevrili, A, B, D ve PP hücrelerinden meydana geldiği (25), ayrıca bu adacıklarda enterokromaffin, vazointestinal polipeptid, gastrin (29) ve ghrelin hücrelerinin bulunduğu bildirilmektedir (1). Kanatlılarda ise endokrin pankreasın alfa, beta ve miks adacıklardan oluştuğu vurgulanmıştır $(11,26)$. Bu çalışmada, Ankara tavşanı pankreasında irili ufaklı çaplarda, oval ya da yuvarlak şekilli endokrin adacıkların A, B ve D hücrelerinden meydana geldiği belirlendi. Endokrin adacıklarda az da olsa görüldüğü bildirilen PP hücrelerine (15), Young ve Heath, (29) ile Adeghate ve Ponery, (1)'nin bildirdiği enteroendokrin sisteme ait hücrelere de rastlanmad.

Histokimyasal boyamalarda A hücrelerinin asidofilik karakterde oldukları, B hücrelerinin aldehit fuksinle, D hücrelerinin ise anilin blue ve light green ile boyandıkları bilinmektedir (12). A hücre granüllerinin, yarı ince kesitlerde ve ince kesitlerde yoğun olarak boyandığı da belirtilmektedir (7). Bu çalışmada, B hücreleri toluidine blue-pironin ile boyanmazken, A hücre granüllerinin Bencosme ve Pease, (7)' in bildirdiği gibi toluidine blue ile pozitif reaksiyon verdiği saptanmıştır. Bouin tespitinden sonra yapılan üçlü boyamada A hücreleri asit fuksinle pembe, B hücreleri aniline blue ile açık mavi renkte reaksiyon verirken, $\mathrm{AF}$ boyamasında $\mathrm{A}$ hücreleri sarımsı-yeşil, B hücreleri mor menekşe renkte reaksiyon gösterdiler. Carnoy tespitinden sonra yapılan üçlü boyamada A hücrelerinin anilin blue ile reaksiyona girerek koyu mavi, B hücrelerinin de asit fuksinle reaksiyona girerek pembe renkte boyandığı, AF boyamasına ise hiçbir endokrin hücrenin yanıt vermediği saptandı. Herhangi bir literatür bilgisine rastlayamadığımız bu konuyla ilgili verilerimize göre, tespit solüsyonları A ve B hücrelerinin boyanma özelliklerini değiştirmektedir.

Langerhans adacıklarındaki A hücreleri atlarda adacıkların merkezinde, koyunda, köpekte, domuzda (4) ve ratta (14) ise periferinde yer alırlar. A hücrelerinin atlarda endokrin adacıklardan başka akıtıcı kanal epitelinde ve asinuslarda da bulunduğu bildirilmektedir $(17,30)$. Işık ve elektron mikroskobik incelemelerimizde $\mathrm{B}$ hücrelerinden daha az sayıda olan $\mathrm{A}$ hücrelerinin koyun, köpek, domuz ve rattaki gibi Langerhans adacıklarının periferinde yerleştikleri tespit edildi. Sığırlarda $\mathrm{A}$ hücreleri $\mathrm{B}$ hücrelerine göre membransel organellerden özellikle gER'dan zengin olduğunu bildirilse de (2), bizim çalışmamızda da Yukawa ve ark. (30)'nın farelerde bildirdiği gibi A hücrelerinin ökromatik yuvarlak bir çekirdeğe, az sayıda gER ve krista tipi mitokondriyonlara sahip olduğu belirlendi. Elektron mikroskobik olarak A hücre granüllerinin kobay, kedi (7), rat $(14,18)$, fare $(30)$ ve tavşanda $(16)$ vakuoler bir membranla sarılı olduğu belirtilmektedir. Ankara tavşanının endokrin pankreasında bu hücrelerin sitoplazmasını çok sayıda yuvarlak şekilli elektron yoğun salg1 granüllerinin doldurduğu, Bencosme ve Pease (7), Kaung (18), El-Naggar (14), Yukawa ve ark. (30) ve Gomez-Acebo ve ark (16)'nın bildirdiği granül içeriği ile membranı arasında belirgin açıklığa sahip granüllerin ise az da olsa bulunduğu belirlendi. Bu granüllerin daha çok çekirdeğe ve Golgi kompleksine yakın olması nedeniyle olgunlaşmamış granüller olabileceği kanaatine varıldı.

İnsülin salgılayarak kan şekerini düşüren $\mathrm{B}$ hücreleri, atlarda adacık periferine yerleşirken $(17,30)$, rat, kobay, köpek, koyun, domuz gibi diğer memelilerde adacık merkezinde bulunmaktadır $(4,30)$. Adacıktaki diğer endokrin hücrelere göre mitokondriyon, Golgi kompleksi ve ER'dan zengin olan $\mathrm{B}$ hücrelerinin çekirdeği ve granülleri de $\mathrm{A}$ hücrelerinin çekirdeği ve 
granüllerinden daha büyüktür $(4,6,30)$. A hücre granülleri türler arasında benzerlik gösterirken, B hücre granülleri farklı şekillerde bulunmaktadır. İnsan, rat, fare ve kobayda yuvarlak (10), kedi ve köpekte poligonal olan granül içeriği (9), köpek (20) ve bıldırcında (26) çubuk tarzında elektron yoğun cisimciklerden oluşur. Ratta B hücrelerinin sitoplazmasında granül ile granül membranı arasında belirgin boşluğa sahip oval şekilli elektron koyu (olgun) granüller ile elektron az yoğun (olgunlaşmamış) yuvarlak granüller bulunduğu (14), bu hücrelerin ergastoplazmadan zengin olmasının elektron mikroskopta diğer endokrin hücrelere göre daha koyu görünmesine neden olduğu da bildirilmektedir (20). Elektron mikroskobik incelemelerimizde, El-Naggar'in, (14) ratta olgun ve olgunlaşmamış olarak tarif ettiği granüllerin Ankara tavşanı B hücre sitoplazmasında da bulunduğu saptandı. Ayrıca, A hücrelerine göre B hücre sitoplazmasında serbest ribozom ve gER yoğunluğunun fazla olduğu belirlense de sitoplazmasında az miktarda granül içeren bazı A hücrelerinin serbest ribozomlardan daha zengin olduğu da tespit edildi.

Endokrin pankreasta ve sindirim sisteminde bulunan D hücreleri somatostatin, vazoaktif intestinal polipeptid (4) ve peptid YY (25) gibi hormonlar salgılamaktadır. Bu hücrelerin, pankreastaki dağılımları ve elektron yoğunlukları türler arasında farklılıklar gösterir. Sığırda (22) ve keçide (24) hem adacık periferinde hem de merkezinde, tavşan ve ratta sadece adacık periferinde yerleşirken, kedide, köpekte ve insanda adacık hücreleri arasına rasgele dağılmıştır (3). Bu hücrelerin atlarda adacık periferinden başka nadiren duktus epitelinde (17), bıldırcında (26), tavukta, kedide ve köpekte hem ekzokrin pankreasta hem de endokrin pankreasta bulunduğu da bildirilmektedir (3). D hücrelerinin sitoplazması, kobayda düzensiz çekirdekli ve orta elektron yoğunlukta küçük granüller içerirken (6), ratta çok sınırlı elektron açık bölgeye sahip orta elektron yoğun granüllü (14), kedide yuvarlak şekilli ve granüllleri az sayıda (7), tavşanda granüller farklı yoğunluklarda (16), farede elektron az yoğunlukta ve çok sayıda granül içermeleri ile diğer endokrin hücrelerden ayırt edilebilir (30). Ankara tavşanının endokrin pankreasinda $A$ ve $B$ hücrelerine göre az sayıda $D$ hücreleri bulunduğu tespit edildi. Bu hücrelerin hem elektron az yoğun hem de elektron çok yoğun oval ya da yuvarlak şekilli az sayıda granülleri olduğu görüldü. Granüllerin genellikle çekirdek etrafındaki dar sitoplazmik alanda tespih taneleri gibi sıralandığ 1 da belirlendi. $\mathrm{Bu}$ özellikleri ile El-Naggar (14), Yukawa ve ark. (30), Baskin ve ark. (6) ile Bencosme ve Pease (7)'nin rat, fare, kobay ve kedide bildirdiği D hücrelerinin histolojik özelliklerinden oldukça farklı bir yapıdaydı.

Sonuç olarak, AF ile boyanan Ankara tavşanı pankreaslarında, endokrin adacıkların merkezini mormenekşe boyanan çok sayıda $\mathrm{B}$ hücresinin, periferini ise sarıms1-yeşil renkte boyanan az sayıda A hücresinin oluşturduğu görüldü. Ayrıca, Carnoy tespiti yapılan pankreaslarda A ve B hücrelerinin üçlü boyamayla kolaylıkla fark edildiği, ancak bu tespit solüsyonunun AF boyaması için uygun olmadığı da belirlendi. Elektron mikroskobik incelemelerde, B hücrelerinin granül içeriği ile granül membranı arasında vakuoler boşlukları bulunan elektron az yoğun ve çok yoğun granülleriyle A hücrelerinden, D hücrelerinin ise çekirdek etrafinda tespih taneleri tarzında dizilen karakteristik granülleriyle A ve $B$ hücrelerinden ayırt edilebileceği tespit edilmiş oldu.

\section{Kaynaklar}

1. Adeghate E, Ponery AS (2002): Ghrelin stimulates insulin secretion from the pancreas of normal and diabetic rats. J Neuroendocrinol, 14, 555- 560.

2. Ali SS, Ali MM, Hering BJ, Bretzel RG, Federlin K (1991): Light- and electron-microscopic studies on isolated bovine islets of Langerhans. Anat Anz, 173, 7380.

3. Aluments J, Sundler F, Hakånson R (1977): Distribution, ontogeny and ultrastructure of somatostatin immunreactive cells in the pancreas and gut. Cell Tissue Res, 185, 465-479.

4. Bacha WJ, Wood LM (1990): Color Atlas of Veterinary Histology. Lea and Febiger, Philadelphia \& London

5. Bancroft JD, Cook HC (1984): Manual of Histological Techniques. Churchill Livingstone Medical Division Longman Group Limited, UK.

6. Baskin DG, Gorray KC, Fujimoto WY (1984): Immunocytochemical identification of cells containing insulin, glucagon, somatostatin, and pancreatic polypeptide in the islets of Langerhans of the guinea pig pancreas with light and electron microscopy. Anat Rec, 208, 567- 578.

7. Bencosme SA, Pease DC (1958): Electron microscopy of the pancreatic islets. Endocrinology, 63, 1- 13.

8. Bertelli E, Regoli M, Bastianini A (1994): Endocrine tissue associated with the pancreatic ductal system: a light and electron microscopic study of the adult rat pancreas with special reference to a new endocrine arrangement. Anat Rec, 239, 71- 78.

9. Bloom W, Fawcett DW (1994): A Textbook of Histology. Twelfth Ed. Chapman and Hall, Sounders Company, Philadelphia, London, Toronto.

10. Böck P, Moneim M, Egerbacher M (1997): Development of pancreas. Microsc Res Techn, 37, 374- 383.

11. Cowap J (1985): The first appearence of endocrine cells in the splenic lobe of the embriyonic chick pancreas. Gen Comp Endocrin, 60, 131- 137.

12. Culling CFA, Allison RT, Barr WT (1985): Cellular Pathology Technique. Fourth Ed. Butterworth \& Co. Ltd. London.

13. Dellmann HD, Eurell J (1998): Textbook of Veterinary Histology. 5nd. Ed. Williams \& Wilkins A Waverly Company, Pennsylvania, USA

14. El-Naggar MM (2000): Ultrastructural immunogold study on the various cell types of cultured pancreatic islets of adult rats. Folia Morphol, 59, 253-262. 
15. Greider MH, Gersell DJ, Gingerich RL (1978): Ultrastructural localization of pancreatic polypeptide in the $F$ cell of the dog pancreas. J Histochem Cytochem, 26, $1103-1108$.

16. Gomez-Acebo J, Parrilla R, R-Candela JL (1968): Fine structure of the $A$ and $D$ cells of the rabit endocrine pancreas in vivo and incubated in vitro. I. mechanism of secretion of the a cells. J Cell Biol, 36, 33- 44.

17. Helmstaedter V, Feurle GE, Forssmann WG (1976): Insulin-, glucagon-, and somatostatin-immunoreactive endocrine cells in the equine pancreas. Cell Tissue Res, 172, 447- 454.

18. Kaung CH (1985): Electron microscopic immunocytochemical localization of glucagon and pancreatic polipeptide in rat pancreas: characterization of a population of islet cells containing both peptides. Anat Rec, 212, 292-300.

19. Karnovsky MJ (1965): Formaldehyde-glutaraldehyde fixative of high osmolality for use in electron microscopy. J Cell Biol, 27, 137A- 138A.

20. Lacy PE (1957): Electron microscopic identification of different cell types in the islets of Langerhans of the guinea pig, rat, rabbit and dog. Anat Rec, 128, 255- 267.

21. Larsson LI (1998): On the development of the islets of Langerhans. Microsc Res Tech, 43, 284- 291.

22. Liman N (1991): Siğır, Koyun ve Keçi'nin Pankreasında A ve B Hücreleri Üzerine Morfolojik çallşmalar. Doktora Tezi, Ankara Üniv. Sağ. Bil. Ens. Ankara.

23. Prado CL, Pugh-Bernard AE, Elghazi L, Sosa-Pineda B, Sussel L (2004): Ghrelin cells replace insulinproducing $B$ cells in two mouse models of pancreas development. Proc Natl Acad Sci, 101, 4679- 4684.

24. Reddy S, Elliott RB (1985): Insulin, glucagon, pancreatic polypeptide hormone and somatostatin in the goat pancreas: demonstration by immunocytochemistry. Ausr J Biol Sci, 38, 59- 66.
25. Slack JMW (1995): Developmental biology of the pancreas. Development, 121, 1569-1580.

26. Şimşek N, Özudoğru Z, Alabay B (2008): Immunohistochemical studies on the splenic lobe of the pancreas in young japanese quails (Coturnix c. japonica), DTW, 115, 189- 193.

27. Veneable JH, Coggeshall R (1965): A simplified lead citrate stain for use in electron microscopy. J Cell Biol, 25, 407-408.

28. Wolfe-Coote SA, Louw J, Woodroof CW, Heydenrych JJ, Du Toit DF (1998): Induction of cell proliferation an differentiation in the pancreas of the adult Vervet Monkey (Cercopithecus Aethiops). Pancreas, 16, 129- 133.

29. Young B, Heath JW (2000): Wheater's Functional Histology. Fourth Ed. Churchill Livingstone, Sydney, Toronto.

30. Yukawa M, Takeuchi T, Watanabe T, Kitamura $\mathbf{S}$ (1999): Proportions of various endocrine cells in the pancreatic islets of wood mice (Apodemus speciosus). Anat Histol Embryol, 28, 13- 16.

Geliş tarihi: 17.10.2009 / Kabul tarihi: 09.01.2009

Yazışma adresi:

Yrd. Doç. Dr. Nejdet Şimşek

Atatürk Üniversitesi, Veteriner Fakültesi,

Histoloji ve Embriyoloji Anabilim Dall,

25700- Ilica/Erzurum.

Tel: 0442 6314193, Fax: 04426314188

e-mail:nsimsek-58@hotmail.com \&

nsimsek58@gmail.com 